\title{
Becker muscular dystrophy: correlation of deletion type with clinical severity
}

\author{
A M Norman, N S T Thomas, H M Kingston, P S Harper
}

\begin{abstract}
Molecular deletion screening with cDNA probes from the dystrophin gene was undertaken in patients with Becker muscular dystrophy from 58 separate families. Deletions were found in $41(71 \%)$ of these families. Thirty-four (83\%) of the deletions started in the same intron near the centre of the gene, and although there was no precise correlation between clinical severity and deletion pattern, the commonest deletion pattern, which was present in $49 \%$ of all deletion families, is associated with a mild phenotype.
\end{abstract}

Becker muscular dystrophy (BMD) has been a major interest of this department since 1981, and we were among the first to show that BMD and Duchenne muscular dystrophy (DMD) were likely to be allelic. ${ }^{1}$ The cloning of the DMD/BMD gene, ${ }^{2}$ and the discovery of its protein product, dystrophin, ${ }^{3}$ has confirmed that mutations in the same gene are indeed responsible for the clinical spectrum of $\mathrm{DMD} / \mathrm{BMD}$, but the details of how the varying severity of phenotypes can be explained by differences in the underlying mutation are not yet fully worked out, though some progress has been made. ${ }^{4}$ Study of BMD, with its greater range of clinical severity and relative homogeneity of molecular deletions, is likely to be more fruitful than study of DMD, where a more narrowly defined phenotype is produced by a wide range of molecular deletions. Several groups have already described series of DMD deletions, ${ }^{5-10}$ but few have included large series of BMD patients. ${ }^{11} \mathrm{We}$

Institute of Medical Genetics, University of Wales College of Medicine, Heath Park, Cardiff CF4 4XN. A M Norman, N S T Thomas, P S Harper

Regional Genetics Centre, St Mary's Hospital, Manchester.

H M Kingston

Correspondence to Dr Norman.

Received for publication 21 September 1989.

Accepted for publication 4 October 1989. report here the $\mathbf{4 1}$ deletions discovered in 58 separate BMD families.

\section{Methods}

Patients and families with BMD were collected from three sources. Firstly patients were referred for confirmation of diagnosis and genetic counselling because of the known interest in muscle disease of our department. Secondly, multigeneration families were collected for the original linkage analysis. ${ }^{1}$ Thirdly, isolated male patients were collected as part of an attempt to distinguish BMD from autosomal recessive limb-girdle muscular dystrophy by means of

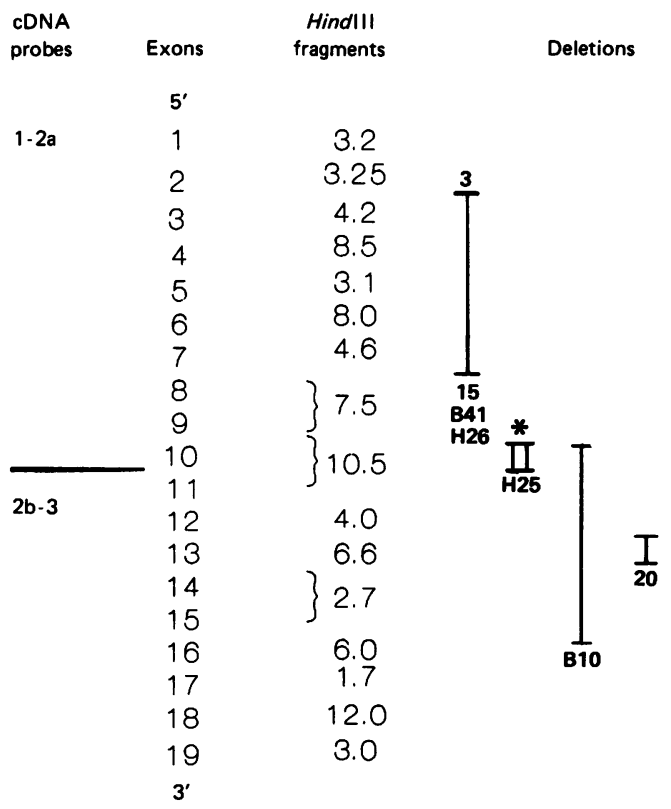

Figure 1 Deletions detected near the centromeric end of the dystrophin cDNA on exon containing HindIII genomic fragment map as published by Darras et al..$^{8}$ Numbers at the top of deletion lines represent number of separate families studied with that deletion. Codes at bottom refer to patients indicated in table $1 .{ }^{*}$ Note patient H25 has a duplication of exon 10 , not a deletion. 
dystrophin cDNA probes. ${ }^{12}$ All patients were examined by one of us and had a proximal limb-girdle pattern of muscle weakness, calf hypertrophy, and either a family history compatible with $\mathrm{X}$ linked inheritance or muscle pathology characteristic of a primary muscular dystrophy or both.

DNA was extracted from venous blood and aliquots were digested to completion with PstI, HindIII, and $M s p I$. They were then subjected to electrophoresis on $0.9 \%$ agarose gels and blotted onto nylon membranes ('Hybond N', Amersham) by the method of Southern. The membranes were hybridised overnight with cDNA probes that had been labelled with ${ }^{32} \mathrm{P}$ by the random hexanucleotide primed method. ${ }^{13}$ Membranes were washed at $65^{\circ} \mathrm{C}$ in $1 \times \mathrm{SSC}(\mathrm{SSC}=0.15 \mathrm{~mol} / \mathrm{l}$ sodium chloride, $0.015 \mathrm{~mol} / \mathrm{l}$ sodium citrate), $0 \cdot 1 \%$ sodium dodecyl sulphate, then exposed to Fuji $x$ ray film with intensifying screens at $-70^{\circ} \mathrm{C}$ for one to seven days.

The cDNA probes used represent a complete clone from the dystrophin gene. ${ }^{2}$ Molecular deletions are indicated by alteration of the normal band pattern on

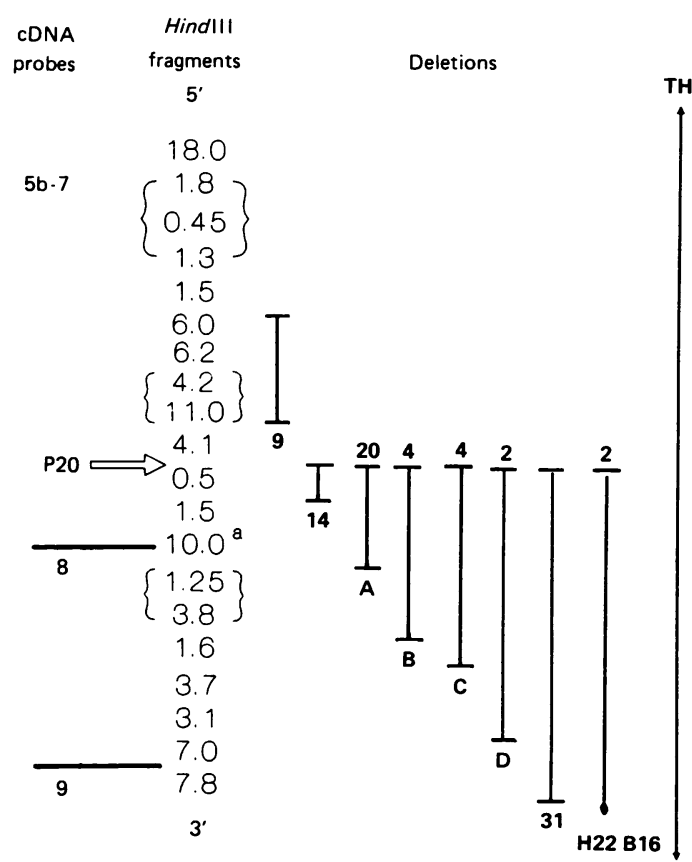

Figure 2 Deletions detected near the centre of the dystrophin cDNA on exon containing HindIII fragment map as published by Darras et al. ${ }^{8}$ (Order of fragments in brackets has not been established. Horizontal arrow indicates position of P20 intron.) Numbers at top of deletion lines represent number of separate families with that deletion. Codes at bottom refer to patients indicated in table 1. Arrows indicate that end of deletion has not been found yet. the autoradiographs. The deletions were mapped onto the HindIII genomic fragment map as published by Darras et al. ${ }^{8}$

\section{Results}

Useful data were obtained on patients from 58 separate BMD families. Molecular deletions were detected in $41(71 \%)$ of these, but only one patient (H25) appeared to have a duplication. Deletion patterns are summarised diagrammatically in figs 1 and 2. Clinical data for each deletion patient or group are summarised in table 1 and for those without a deletion in table 2 . In $20(49 \%)$ of the families with a deletion, there was a common pattern of deleted exons $(0 \cdot 5,1 \cdot 5$, and $10 \mathrm{~kb})$. In total, $34(83 \%)$ of the deletions started in the same intron (between 4.1 and $0.5 \mathrm{~kb}$ exons). The extent of the deletion within this intron was variable, as shown in table 3 by the results of deletion screening with the intronic probe P20.

\section{Discussion}

We report here an extensive series of BMD deletions. Our finding that $71 \%$ of BMD families have a molecular deletion detectable with cDNA probes agrees with the work of others. 511 Our results show that $83 \%$ of these deletions start in the same intron and confirm the findings of Forrest et al. ${ }^{11}$ The start site of the deletion within this 'hotspot' is variable (table 3). ${ }^{14}$ Other workers have disagreed with these conclusions but have only reported small numbers. ${ }^{15}$

It is difficult to correlate clinical severity with deletion type within BMD and this is probably in part the result of individual and personal factors that are likely to affect age at diagnosis and age of acceptance of a wheelchair for mobility in any slowly progressive, chronic disease such as BMD. Furthermore, patients are being seen at different points in the natural history of their disease and this makes assessment of clinical severity difficult, especially in the young isolated case. Nevertheless, the common BMD deletion appears to predict a mild phenotype, as the index patients studied were all still ambulant at a mean age of 34 , and in familial cases no patient in older generations had been confined to a wheelchair before the age of 41. This particular deletion pattern is rarely seen in DMD. In contrast to this, it can be seen by inspection of figs 1 and 2 and table 1 that other deletion patterns have been associated with more divergent phenotypes, as has also been reported by others. ${ }^{6} 16$

Correlation of phenotype and genotype between DMD and BMD is a different matter. Others have shown that DMD deletions are varied in position and extent; our data clearly show that BMD deletions are much more homogeneous. It has been proposed by Monaco $e t a l^{4}$ that deletions which disrupt the codon 
Table 1 Summary of clinical details of patients in study with a deletion (or duplication).

\begin{tabular}{|c|c|c|c|c|}
\hline Patient code & Date of birth & Age at diagnosis $(y)$ & Wheelchair & CK \\
\hline $\begin{array}{r}15 \\
\text { B41 } \\
\text { H26 }\end{array}$ & $\begin{array}{l}1973 \\
1966 \\
1961\end{array}$ & $\begin{array}{r}9 \\
5 \\
11\end{array}$ & $\begin{array}{l}\text { No } \\
18 \\
\text { No }\end{array}$ & $\begin{array}{l}8000 \\
2248 \\
1398\end{array}$ \\
\hline B10 & 1946 & 20 & 32 & 801 \\
\hline H25 & 1947 & 34 & No & 2499 \\
\hline 20 & 1950 & 18 & No & 994 \\
\hline 9 & 1971 & 12 & No & 5050 \\
\hline 14 & 1965 & 11 & No & 1880 \\
\hline $\begin{array}{r}\text { Group A } 2 \\
5 \\
6 \\
7 \\
10 \\
13 \\
18 \\
22 \\
23 \\
\text { B2 } \\
\text { B11 } \\
\text { B38 } \\
\text { B67 } \\
\text { H4 } \\
\text { H6 } \\
\text { H8 } \\
\text { H11 } \\
\text { H12 } \\
\text { H19 } \\
\text { H21 }\end{array}$ & $\begin{array}{l}1954 \\
1947 \\
1956 \\
1967 \\
1969 \\
1966 \\
1956 \\
1949 \\
1935 \\
1945 \\
1965 \\
1926 \\
1957 \\
1970 \\
1946 \\
1961 \\
1936 \\
1960 \\
1950 \\
1963\end{array}$ & $\begin{array}{l}21 \\
17 \\
21 \\
11 \\
13 \\
20 \\
11 \\
20 \\
25 \\
26 \\
13 \\
32 \\
25 \\
13 \\
5 \\
19 \\
15 \\
11 \\
19 \\
12\end{array}$ & $\begin{array}{l}\text { No } \\
\text { No } \\
\text { No } \\
\text { No } \\
\text { No } \\
\text { No } \\
\text { No } \\
\text { No } \\
\text { No } \\
\text { No } \\
\text { No } \\
\text { No } \\
\text { No } \\
\text { No } \\
\text { No* } \\
\text { No:* } \\
\text { No:* } \\
\text { No } \\
\text { No* } \\
\text { No }\end{array}$ & $\begin{array}{r}1730 \\
610 \\
1700 \\
4620 \\
4220 \\
2750 \\
8820 \\
1180 \\
739 \\
729 \\
1223 \\
912 \\
691 \\
4164 \\
1487 \\
2119 \\
415 \\
2331 \\
816 \\
1514\end{array}$ \\
\hline $\begin{array}{r}\text { Group A Mean } \\
\text { (SD) }\end{array}$ & $\begin{array}{c}34 \cdot 1 \\
(11 \cdot 8)\end{array}$ & $\begin{array}{l}17 \cdot 5 \\
(6 \cdot 4)\end{array}$ & None & $\begin{array}{c}2139 \\
(1964)\end{array}$ \\
\hline $\begin{array}{r}\text { Group B } 4 \\
11 \\
\text { B24 } \\
\text { H14 }\end{array}$ & $\begin{array}{l}1949 \\
1970 \\
1964 \\
1959\end{array}$ & $\begin{array}{l}26 \\
11 \\
18 \\
17\end{array}$ & $\begin{array}{l}\text { No } \\
\text { No } \\
\text { No } \\
\text { No }\end{array}$ & $\begin{array}{r}908 \\
1430 \\
2391 \\
4038\end{array}$ \\
\hline 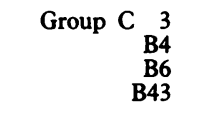 & $\begin{array}{l}1966 \\
1948 \\
1940 \\
1947\end{array}$ & $\begin{array}{l}11 \\
10 \\
20 \\
13\end{array}$ & $\begin{array}{l}17 \\
30 \\
31 \\
40\end{array}$ & $\begin{array}{r}2630 \\
1967 \\
397 \\
2278\end{array}$ \\
\hline Group ${\underset{\mathrm{H}}{\mathrm{H} 17}}_{\mathrm{H} 20}$ & $\begin{array}{l}1945 \\
1970\end{array}$ & $\begin{array}{r}9 \\
11\end{array}$ & $\begin{array}{l}29 \\
\text { No }\end{array}$ & $\begin{array}{r}718 \\
4079\end{array}$ \\
\hline 31 & 1931 & 36 & 53 & 499 \\
\hline $\begin{array}{l}\text { B16 } \\
\mathrm{H} 22\end{array}$ & $\begin{array}{l}1967 \\
1965\end{array}$ & $\begin{array}{l}13 \\
15\end{array}$ & $\begin{array}{l}\text { No } \\
\text { No }\end{array}$ & $\begin{array}{l}4000 \\
3416\end{array}$ \\
\hline TH & 1931 & 45 & No & 609 \\
\hline
\end{tabular}

Patient codes without a prefixed letter identify patients included in the previous study of isolated cases. ${ }^{12}$ Patient codes prefixed by letter $\mathrm{H}$ identify patients included in the original linkage study.' Other patients are taken from the Wales BMD register. Deletions for each patient or group are shown in figs 1 and 2.

$\mathrm{CK}=$ serum creatine kinase activity in IU/l.

${ }^{*}$ Maternal uncle in wheelchair at ages $55,43,49$, and 41 respectively.

reading frame lead to DMD and those which maintain an open reading frame lead to BMD. However, three of our patients (15, B41, H26), all deleted for exons 3 to 7 (fig 1), have previously been reported to have a frameshift deletion. It has been proposed that reinitiation from a fresh start site allows production of functional dystrophin. ${ }^{17}$ The deletion in patient 9 is also of interest because Kunkel recently hypothesised that deletions upstream of the $4 \cdot 1 / 0 \cdot 5 \mathrm{~kb}$ intron (Wapenaar's hotspot) would lead to a very slight defect with either very mild symptoms or none at all, and this might account for the rarity of such deletions. ${ }^{18}$ This patient certainly has very mild disease. 
Table 2 Summary of clinical details of patients in study without a deletion.

\begin{tabular}{|c|c|c|c|c|}
\hline Patient code & Date of birth & Age at diagnosis $(y)$ & Wheelchair & CK (IU/I) \\
\hline 1 & 1957 & 30 & No & 3210 \\
\hline 8 & 1966 & 10 & No & 2650 \\
\hline 12 & 1969 & 11 & 17 & 1880 \\
\hline 16 & 1942 & ii & Yes & 396 \\
\hline 17 & 1954 & 11 & No & 8820 \\
\hline $\mathrm{B} 1$ & 1950 & 20 & 37 & $\begin{array}{r}0020 \\
380\end{array}$ \\
\hline B8 & 1968 & 8 & No & 10097 \\
\hline B23 & 1968 & 14 & No & 4198 \\
\hline B28 & 1968 & 9 & No & 2105 \\
\hline B29 & 1970 & 3 & 14 & 2000 \\
\hline B48 & 1958 & 12 & No & - \\
\hline B61 & - & - & - & - \\
\hline H9 & $\overline{1947}$ & $\overline{13}$ & 33 & 76 \\
\hline H18 & 1959 & 11 & No & 367 \\
\hline $\mathrm{H} 23$ & 1955 & 8 & 15 & 4870 \\
\hline $\mathrm{H} 30$ & 1960 & 13 & 23 & - \\
\hline $\begin{array}{r}\text { Mean } \\
\text { (SD) }\end{array}$ & $\begin{array}{l}29 \cdot 4 \\
(8 \cdot 7)\end{array}$ & $\begin{array}{c}13 \cdot 3 \\
(7 \cdot 0)\end{array}$ & 一 & $\begin{array}{r}2997 \\
(2997)\end{array}$ \\
\hline
\end{tabular}

Patient codes as for table 1 .

${ }^{*}$ Maternal uncle in wheelchair at age 45 .

Table 3 Summary of findings with the intronic probe 120 in deletion patients with start point in this intron $(n=34)$.

All bands deleted

Some bands deleted

No bands deleted

Altered band sire

(implies junction fragment

Examination of muscle dystrophin in this cohort of patients is likely to illuminate further the relationship between gene deletion pattern and clinical severity.

We thank L M Kunkel (Boston, USA), R G Worton (Toronto, Canada), Kay Davies (Oxford), and G van Ommen (Leiden, The Netherlands) for kindly donating DNA probes. This work was supported by the Muscular Dystrophy Association of America and the Muscular Dystrophy Group of Great Britain.

1 Kingston HM, Harper PS, Pearson PL, Davies KE, Williamson $R$, Page $D$. Localisation of the gene for Becker muscular dystrophy. Lancet 1983;ii:1200.

2 Koenig M, Hoffman EP, Bertelson CJ, Monaco AP, Feener C, Kunkel LM. Complete cloning of the Duchenne muscular dystrophy (DMD) CDNA and preliminary genomic organization of the DMD gene in normal and affected individuals. Cell 1987;50:509-17.

3 Hoffman EP, Brown RH, Kunkel LM. Dystrophin: the protein product of the Duchenne muscular dystrophy locus. Cell 1987;51:919-28.

4 Monaco AP, Bertelson CJ, Liechti-Gallati S, Moser H, Kunkel LM. An explanation for the phenotypic differences between patients bearing partial deletions of the DMD locus. Genomics 1988;2:90-5.
5 Forrest SM, Smith TJ, Cross GS, et al. Effective strategy for the prenatal prediction of Duchenne and Becker muscular dystrophy. Lancet 1987;ii: 1294-7.

6 Forrest SM, Cross GS, Speer A, Gardner-Medwin D, Burn J, Davies KE. Preferential deletion of exons in Duchenne and Becker muscular dystrophies. Nature 1987;329:638-40.

7 Read AP, Mountford RG, Forrest SM, Kenwrick SJ, Davies KE, Harris R. Patterns of exon deletions in Duchenne and Becker muscular dystrophy. Hum Genet 1988;80:152-6.

8 Darras BT, Blattner P, Harper JF, Spiro JF, Alter S, Francke U. Intragenic deletions in 21 Duchenne muscular dystrophy (DMD)/Becker muscular dystrophy (BMD) families studied with the dystrophin CDNA: location of breakpoints on HindIII and BgIII exon containing fragment maps, meiotic and mitotic origin of the mutations. Am f Hum Genet 1988;43:620-9.

9 Lindlof $M$, Kiuru A, Kaariainen H, et al. Gene deletions in Xlinked muscular dystrophy. Am F Hum Genet 1989;44:496-503.

10 Upadhyaya M, Smith RA, Thomas NST, Norman AM, Harper PS. Intragenic deletions in 164 boys with Duchenne muscular dystrophy studied with the dystrophin cDNA. Clin Genet (in press).

11 Forrest SM, Cross GS, Flint T, Speer A, Robson KJH, Davies $\mathrm{KE}$. Further studies of gene deletions that cause Duchenne and Becker muscular dystrophies. Genomics 1988;2:109-14.

12 Norman A, Thomas N, Coakley J, Harper P. Distinction of Becker from limb-girdle muscular dystrophy by means of dystrophin cDNA probes. Lancel 1989;i:466-8.

13 Feinberg AP, Vogelstein B. A technique for radiolabelling DNA restriction endonuclease fragments to high specific activity. Anal Biochem 1983;132:6-13.

14 Wapenaar MC, Kievits T, Hart KA, et al. A deletion hotspot in the Duchenne muscular dystrophy gene. Genomics 1988;2: 101-8.

15 Medori R, Brooke MH, Waterston RH. Genetic abnormalities in Duchenne and Becker dystrophies: clinical correlations. Neuro$\log v$ (Minneap) 1989;39:461-5.

16 Baumbach LL, Chamberlain JS, Ward PA, Farwell NJ, Caskey CT. Molecular and clinical correlations of deletions leading to Duchenne and Becker muscular dystrophies. Neurology (Minneap) 1989;39:465-74.

17 Malhotra SB, Hart KA, Klamut HJ, et al. Frameshift deletions in patients with Duchenne and Becker muscular dystrophy. Science 1988;242:755-9.

18 Mandel JL. Dystrophin the gene and its product. Nature 1989;339:584-6. 